\title{
Expanding technical assistance for urban agriculture: Best practices for extension services in California and beyond
}

\author{
Kristin A. Reynolds ${ }^{\mathrm{a}, \mathrm{b}}$
}

Submitted 3 February 2011 / Accepted 6 May 2011 / Published online 3 June 2011

Citation: Reynolds, K. (2011).Expanding technical assistance for urban agriculture: Best practices for extension services in California and beyond. Journal of Agriculture, Food Systems, and Community Development, 1(3), 197-216. http://dx.doi.org/10.5304/jafscd.2011.013.013

Copyright (C) 2011 by New Leaf Associates, Inc.

\begin{abstract}
Past studies have suggested the expansion of extension programs for urban agriculture (UA). With the growing interest in $\mathrm{UA}$, the case for such programs is even stronger. In order to develop effective extension programs, it is important to begin with an understanding of the diversity of UA activities and the types of assistance that may be useful to operators. It is also important to explore whether extension staff are interested in expanding their programs in urban areas. This study sought to address these questions. It examined characteristics

${ }^{a}$ University of California Small Farm Program and Geography Graduate Group, One Shields Avenue, Davis, CA 95616 USA

b Present address: Andrew W. Mellon Post-Doctoral Fellow in Sustainable Urban Food Systems, The New School, 72 Fifth Avenue, Room 525, New York, NY 10011 USA; karfireynolds@gmail.com

Disclosures: The author was employed with the UC Small Farm Program from 2003 to 2009. In 2010 she joined the board of one of the urban agriculture operations included in this study. This was after the data-collection stage of this study ended in 2008. This paper follows up and expands on a research brief that presented preliminary findings from this study, as noted in the Research Methods section of this paper and included in the reference list under Reynolds, K. (2009).
\end{abstract}

of UA in the study area, Alameda County, California; operators' challenges and assistance needs; and Extension staff members' interest in expanding programming for urban agriculture. Data was collected through the University of California Small Farm Program from 2006 to 2009, and consisted of on-site interviews with 52 urban farmers and gardeners as well as surveys of Extension staff members and participant observation, which took place throughout the study.

\section{Keywords}

Alameda County, community gardens, Cooperative Extension, food justice, small farms, University of California, urban agriculture, urban farming, urban gardening, USDA

\section{Introduction}

The three sisters - squash, beans, and corn flourish on a street corner in a wealthy section of town. Cattle graze within view of suburban housing developments. A beekeeper tends his hives under a highway, just blocks from an emergency food provider. Though perhaps surprising to the unknowing eye, these are typical scenes in many metropolitan areas today. They are examples of 
urban agriculture (UA), which can be defined as agricultural production located in and near urban centers, and that which is integrated in the urban economic, social, and ecological system (see Mougeot, 2005; van

Veenhuizen, 2006).

Urban food production is not a new phenomenon. Since at least the nineteenth century, cities as well as their surrounding landscapes and communities have been host to backyard farms, large-scale public gardens, and educational and market gardens, to name a few examples of UA (Bellows, Robinson, Guthrie, Meyer, Peric, \& Hamm, 2000; Blecha, 2007; Hyden-Smith, 2009; Lawson, 2005). The most recent turn toward urban agriculture has been bolstered by the economic crisis, widespread recognition of climate change, rising costs of fuel and food, and the need among many households reduce their food expenditures. This new UA movement has been led by operators, researchers, advocates, and public officials who have recognized the positive role of UA in today's agrifood system. At a federal level, this recognition was symbolized by first lady Michelle Obama's kitchen garden, installed at the White House in 2010 (Burros, 2009). Still, despite enthusiasm from various sectors, support for UA has only begun to address the many social, political, and technical barriers that have limited its success.

In the mid-1990s, U.S.-based research began to explore the multiple community- and personaldevelopment aspects of urban agriculture (see Bellows, Brown, \& Smit, 2003; Brown, 2002; Brown \& Carter, 2003; Feenstra, McGrew, \& Campbell, 1999; Hynes, 1996; Kaufman \& Bailkey, 2000; Lawson, 2005). Since then, studies have documented the many benefits of UA, which range from food access to environmental conservation; drawbacks, such as the contaminated state of many urban soils; and challenges, which one study categorized as being related to procedure, government, production site, and perception (Kaufman \& Bailkey, 2000). These benefits, drawbacks, and challenges are summarized in tables 1 and 2.

More recently, studies have inventoried land suitable for food production and reviewed municipal policies that might support or hinder urban agriculture (Balmer et al., 2005; Jones, Ona, Rimkus, \& Wells, 2005; McClintock \& Cooper, 2009; Unger \& Wooten, 2006). In addition to providing useful baseline data, these studies have stood as calls for government agencies and city planners to recognize the potential role of UA in urban resiliency and to take measures to ensure agriculture as a long-term use of urban land.

Over the past two decades, several studies have also made recommendations about overcoming challenges to UA, including raising awareness about the benefits of urban food production; addressing food production through city planning; developing policy measures that facilitate urban agriculture; increasing public acceptance of food production in cities; and increasing technical support and extension services for UA (Brown \& Carter, 2003; Feenstra et al., 1999; Kaufman \& Bailkey, 2000; Pothukuchi \& Kaufman, 1999; Smit, Ratta, \& Nasr, 1996). Suggestions for expanding extension services have included:

- integration of urban food-system topics within research and extension programs (Brown \& Carter, 2003; Feenstra et al., 1999);

- a return of extension to urban areas (Brown \& Carter, 2003; Feenstra et al., 1999);

- applied ecological and agronomic research for urban and culturally diverse settings (Brown \& Carter, 2003; Feenstra et al., 1999; Schertenleib, Forster, \& Belevi, 2002);

- community-based leadership development for UA and community food security (Brown \& Carter, 2003);

- education and demonstrations related to the environmental- and public-health risks of soil contamination (Brown \& Carter, 2003; Drescher, 2002); and

- facilitation of information exchange between regions (Smit et al., 1996).

This study sought to explore how related California Extension programs might expand assistance for urban agriculture. 
Table 1. Benefits and Drawbacks of Urban Agriculture Cited in U.S. Literature

\section{Benefits $^{a}$}

Food access and public health

- increased access to healthy, fresh, culturally acceptable foods

- increased affordability of healthy, fresh, culturally acceptable foods

- opportunity for exercise and physical activity through food production

Community and environment

- personal or community development

- community and economic development

- increased or maintained open and green space

Education and training

- educational and job training

- employment opportunities for socially marginalized groups

- youth development

Psychological and cultural

- access to open/green space

- stress relief

- contact with nature

- control of public space

- relaxation

- spiritual connections

- cultural continuity for some immigrant groups

- feeling of creating and participating in an alternative food system

\section{Drawbacks $^{b}$}

Public health and environmental risks related to:

- improper organic waste disposal (i.e., food and animal waste) due to lack of knowledge and/or lack of access to proper disposal facilities

- incomplete knowledge about sanitation and safety when keeping livestock

- use of brownfields or other contaminated sites

- lack of knowledge and resources (funds, land, etc.) to remediate soil

a Sources: Ashton, 2003; Bellows et al., 2003; Blecha, 2007; Brown, 2002; Brown \& Carter, 2003; Eizenberg, 2008; Feenstra et al., 1999; Francis, 1987, 1989; Hynes, 1996; Kaufman \& Bailkey, 2000; McGrew, 1999; Monroe-Santos, 1998; Pothukuchi \& Kaufman, 1999.

b Sources: Dufour, 2009; Kaufman \& Bailkey, 2000

\section{Table 2. Challenges to Urban Agriculture} Cited in U.S. Literature ${ }^{a}$

Procedure-related

- inadequate financial resources for start-up costs, ongoing operations, or staff

- difficulties of integrating food production with social objectives

- lack of financial self-sufficiency and/or reliance on grants for funding

- lack of sound business planning

- lack of access to markets

- seasonal limits

- health risks

Government-related

- zoning

- city planning

- governmental restrictions

- lack of political support

Site-related

- site contamination

- security

- land tenure

- vandalism

- crime

Perception-related

- perception that agriculture is not a legitimate urban activity

- negative perception of cultivating food in cities

- association between food production and exploitation among some cultural groups (e.g., African Americans, Latinos)

a Categories based on Kaufman \& Bailkey, 2000. Sources: Brown, 2002; Brown \& Carter, 2003; Feenstra et al., 1999; Kaufman \& Bailkey, 2000; Pothukuchi \& Kaufman, 1999; Smit, Ratta, \& Nasr, 1996.

\section{Precedents: USDA and Cooperative Extension Programs}

Cooperative Extension is the national system through which the U.S. Department of Agriculture (USDA)'s National Institute of Food and Agriculture (NIFA) partners with land grant universities in each state to provide research-based information to the public (National Institute of Food and Agricul- 
ture (NIFA), 2011). Today, the Cooperative Extension (CE) system includes six major areas: youth development, agriculture, leadership development, natural resources, family and consumer sciences, and community and economic development (NIFA, 2011). Urban agriculture may encompass these issues as well, yet CE has often overlooked the scope of urban food production, resulting in the gaps mentioned above (Brown \& Carter, 2003; Feenstra et al., 1999).

Although there is currently no systemwide Cooperative Extension program focused on urban agriculture, USDA programs have facilitated urban food production in the past. The first of these UAfocused USDA programs was the Victory Garden campaign of World War II. Following on the tails of government-driven urban garden programs of World War I and the Depression era (which were sponsored by the War Department and the Works Progress Administration, respectively), the Victory Garden campaign urged residents to grow their own food so that a greater proportion of commercial agricultural products could be sent to armed forces abroad (Hyden-Smith, 2009; Hynes, 1996; Lawson, 2005). Up to $44 \%$ of the nation's vegetables were grown in Victory Gardens during World War II (Hyden-Smith, 2009, p. xii; Hynes, 1996). Despite the success and popularity of Victory Gardens, USDA support for urban food production tapered off after World War II.

The USDA's next urban food production program began in 1964, when a county Cooperative Extension director in Philadelphia began to establish community gardens on vacant city lots (Stephens, DelValle, Daniels, \& Oehler, 1996). This program developed alongside community-led urban garden initiatives in the wake of that decade's race riots, which had resulted in injuries, arrests, and the closing of local businesses in many urban communities (Stephens, DelValle, Daniels, \& Oehler, 1996). Eight years later, a CE agent in Washington state began the Master Gardener Program (MGP), which trained volunteers to provide horticultural advice to home gardeners (Malakoff, 1994). The MGP eventually expanded to 45 states with funding from state departments of agriculture and the
USDA (Geisel \& Feathers, n.d.; Gibby, Scheer, Collman, \& Pinyuh, n.d.). Today, MGP focuses primarily on home horticulture and pest management issues, and is coordinated at the state and county levels. MGP is complemented in some areas by related "master" programs in composting, food preservation, and/or beekeeping.

At the federal level, legislators initiated a national USDA Urban Garden Program (UGP) in 1976. In contrast to the MGP, which relies on volunteers to conduct education for home gardeners in general (with no explicit focus on urban areas), the UGP employed CE agents to "assist in teaching and demonstrating gardening and 4-H type work [e.g., small livestock husbandry], as well as nutrition assistance for low-income families" in large cities (Schaller, 1977, as cited in Stephens et al., 1996, p. 294). Volunteers from the MGP and related master programs were trained to work alongside CE staff. During its first year of operation, the UGP helped create opportunities for low-income residents to grow and preserve vegetables in New York City, Chicago, Los Angeles, Philadelphia, Detroit, and Houston (Hynes, 1996). By 1989 over 3,000 UGP staff and volunteers worked with 200,000 lowincome urban gardeners, producing US\$22.8 million worth of produce on a budget of US $\$ 3.5$ million (Hynes, 1996, p. 90).

The UGP eventually expanded to 23 cities, until changes in the 1994 federal budget reduced its funding and eventually brought it to an end (Malakoff, 1994; see also Hynes \& Howe, 2002; Lawson, 2005; Stephens et al., 1996). A handful of regional $\mathrm{CE}$ agencies have continued to operate urban agriculture programs, including the Los Angeles County Common Ground Garden Program, which targets low-income city residents and traditionally underrepresented families for its food production and nutrition education program (Los Angeles County Cooperative Extension, n.d.). However, the UGP's dual focus on food production (including animal husbandry) and nutrition education for low-income urban residents has not been replicated at a national level.

Although CE has faced budget shortfalls in recent 
years, its mission to deliver research-based education to the public remains intact. This, along with the growing number and diversity of UA operations, suggests that a more comprehensive focus on UA within the CE system is needed. This paper seeks to address this gap by assessing the needs for and possibility of expanding extension services for a diversity of UA operators.

\section{Overview of Study}

This study was conducted in Alameda County, California (in the San Francisco Bay Area) and within the University of California's Small Farm Program and Small Farm Workgroup from 2006 to 2009. The goals of the study were to (a) assess the types of urban agriculture in the study area; (b) explore UA operators' need for technical assistance; and (c) assess county and statewide Extension staff members' understanding of and interest in expanding technical assistance for UA.

Three extension programs were integral to this study. Alameda County Cooperative Extension (UCCE Alameda) is the extension office that serves the study area. Although UCCE Alameda does not have an UA program, it does have environmental horticulture, nutrition education, youth development, MGP, and school garden programs (University of California Cooperative Extension Alameda County, n.d.). The county director has also been involved with urban foodsystems research and has expressed interest in expanding assistance for UA operators. The statewide UC Small Farm Program (SFP) was established in 1979 to provide extension assistance to California's small-farm community. The related UC Small Farm Workgroup is composed of extension advisors ${ }^{1}$ and other small-farm stakeholders who address small-farm issues. Each of these programs is part of UC's Division of Agriculture and Natural Resources, which houses California's Extension system. ${ }^{2}$

\footnotetext{
1 "Extension advisors" in the California extension system are equivalent to agricultural extension agents in other states.

2 UC DANR announced that it would close the UC Small Farm program in 2009, although the program has restructured
}

\section{Study Context}

As a part of the nine-county San Francisco Bay Area, Alameda County is home to the densely populated cities of Oakland and Berkeley on the bay, as well as less dense yet growing suburbs to the east. Land use in the eastern part of Alameda County currently includes cattle grazing, parklands, and a limited amount of crop production, as well as housing developments and ranchettes. ${ }^{3}$ As of 2006 there were 253,386 acres of agricultural land in Alameda County, with 1,727 acres having been converted to nonagricultural use between 2004 and 2006 (California Department of Conservation, 2008). In 2007, the Census of Agriculture counted 525 farms, with an average farm size of 390 acres (U.S. Department of Agriculture (USDA), 2007). This represented a $24 \%$ increase in the number of farms, and a $24 \%$ decrease in average farm size as compared with the prior census (USDA, 2002). The majority of agricultural production consists of hay, pasture, plant nurseries, and wine grapes, with produce and nuts totaling only $1.5 \%$ of the economic value of agriculture in 2007, the first year of the field research (Bray, 2008). There are also many urban farms and gardens in the county that produce fruits, vegetables, herbs, honey, and/or livestock products. However, these activities have generally not been reflected in agricultural statistics. ${ }^{4}$

As a whole, Alameda County is demographically diverse and includes sizable populations of White, Asian, Hispanic/Latino, African American, and American Indian/Native Alaskan persons. Median household income in the county was US\$68,263 in 2007 (U.S. Census Bureau, 2008), yet historical economic inequalities persist. In 2006, for example, $11.2 \%$ of the overall population lived in poverty, yet African American and Latino groups were overrepresented in these statistics when compared

and continues to operate (Jolly, 2009; Small Farm Program, n.d.).

${ }^{3}$ The American Farmland Trust (n.d) describes ranchettes as residences built on lots of 1.5 acres or more.

${ }^{4}$ The Alameda County Department of Agriculture, Weights, and Measures began to include community gardens in its annual crop report in 2009 . 
with White and Asian groups (Beyers et al., 2008, pp. 41-54).

In addition to income and poverty, inequalities also extend to the food system in Alameda County. For instance, while parts of the county are known for upscale restaurants, farmers' markets, and specialty grocers defined by their focus on farm-fresh products, numerous studies have documented lack of access to fresh, healthy, affordable, and culturally appropriate foods in certain communities (see Alkon, 2008; Beyers et al., 2008; Cozad, King, Krusekopf, Prout, \& Feenstra, 2002; FarfanRamirez, n.d.; Farfan-Ramirez \& Kelly, n.d.; Fuller, n.d.; Guthman, 2003; Heynen, 2009; Short, Guthman, \& Raskin, 2007; Tsai, 2003). A recent countywide health assessment, for instance, found that access to healthy food (e.g., fresh produce, meat, and dairy) was "highly dependent on the neighborhood in which one lives" (Beyers et al., 2008), and past studies have noted that low-income residents of West Oakland (a historically African American district that also has a sizable Southeast Asian population) have struggled for decades with these issues (Alkon, 2008; Farfan-Ramirez, n.d.; Farfan-Ramirez \& Kelly, n.d.; McClintock, 2008). Urban agriculture has surfaced as a way to address some of the food system issues mentioned here.

\section{Research Methods}

There were two populations of interest in this study: (1) key informants from urban agriculture operations (UA operators); and (2) Farm advisors and staff members (Extension staff) from the UC Small Farm Program, Small Farm Workgroup, and UCCE Alameda. Multiple methods were used to collect data, as described below.

\section{Study Population 1}

The UA operators in this study were gardeners and production managers from 52 farms, gardens, and apiculture and/or mushroom-foraging operations located in Alameda County. Operations were included in the study if they: (a) made edible products available to the public through sales and/or community distribution; (b) provided land to urban residents for food production; and/or (c) consisted of household members producing a significant part of their own food at their place of residence. (This study did not examine smaller backyard gardens, school gardens, or agricultural operations that produced only non-edible products, such as nurseries or hay producers.) Individual participants were selected through snowball sampling, which uses stakeholder input to identify key informants.

Data collection with UA operators took place between mid-2007 and early 2008, and consisted of site visits and interviews. A set of open- and closeended interview questions was developed with input from local stakeholders. Questions probed characteristics of the operations, agronomic techniques, community development strategies, challenges, and needs for technical assistance. At the beginning of each interview informants were given the most recent SFP newsletter in order to familiarize them with the focus of the program.

Interviews were recorded and transcribed by the author. Responses were analyzed for common themes and subsequently coded for further analysis using the SPSS software package, although the author recognizes the limitations of this approach. UA operations can have numerous functions and, more generally, categories imposed by a researcher risk oversimplifying groups' and individuals' roles and motives. In order to minimize this risk, preliminary findings were shared with a selection of UA operators and Extension staff in the form of a 12page research brief, and feedback was incorporated into the final analysis (see Reynolds, 2009). This helped verify the validity of the research findings and maintained study participants' voices in the research process.

A series of maps was also created with site location and U.S. Census data using GIS software. This enabled further geographic and demographic analysis. Analysis of these maps is included in the author's dissertation (Reynolds, 2010).

\section{Study Population 2}

Extension key informants (Extension staff) consisted of SFP advisors, members of the UC Small Farm Workgroup, and staff members from 
UCCE Alameda, who had expressed interest in urban agriculture. Data were collected through participant observation ${ }^{5}$ of three types of intervention: (a) a study tour of Bay Area urban production and marketing sites, organized in fall 2006 to familiarize Extension staff with urban agricultural and food issues; (b) facilitated discussions about UA, which took place between 2007 and 2009; and (c) email surveys of Extension staff, which were administered immediately after the study tour and the facilitated discussions. Field notes and written survey responses were analyzed for common themes.

\section{Limitations of This Study}

One limitation of this study was that Alameda County Cooperative Extension has no farm advisors. This, along with budgetary constraints within the entire University of California Extension system, limited the potential to develop a new UA program. Nevertheless, the study addressed issues that could be approached through innovative program planning and that are applicable beyond the study area.

The small sample size among the UA operator population $(n=52)$, also limited the inferences that could be drawn from the findings. Nonetheless, use of characteristic themes for analysis and discussion may be a useful framework for communicating about the diversity of UA operations.

\section{Findings Part One: Urban Agriculture Operators}

\section{Main Purpose}

Key informants were asked questions about the characteristics and main purpose of their

\footnotetext{
${ }^{5}$ Participant observation is a qualitative research methodology in which an investigator establishes and maintains a manysided and situationally appropriate relationship with an individual or group in a natural setting for the purpose of developing a social scientific understanding of that association. This may entail participation in and intentional observation of normal activities or planned interventions, as well as documentation of observations through field notes (Lofland, Snow, Anderson, \& Lofland, 2006, pp. 16-19).
}

operations. The following four themes emerged through analysis of these responses.

Theme one: Community gardens and orchards (CG). Community gardening is perhaps the most familiar example of UA. Community gardens and orchards (CGs) in this study provided garden space to community members to grow produce, herbs, and flowers for themselves and family members. Many gardens also integrated native plants into the garden space. Sales of garden products were prohibited in most cases.

City agencies, regional government districts, and/or nonprofit organizations provided resources and oversight of garden sites for most of the community gardens in this study. These included one or more of the following: a staff coordinator, land tenure, water supply, basic site maintenance (e.g., trash collection), and other resources (tools, donated seeds, etc.). Gardeners typically paid a small annual fee (between US\$10 and US\$75) to the coordinating agency or organization for these services. In some cases the staff coordinator was highly involved with all aspects of the garden, from registering new members and assigning plots to providing supplies. In other cases, gardeners themselves formed committees that managed these and other activities, including public garden days and seasonal garden clean-ups.

\section{Theme two: Community food security; food justice; youth development (CFS/FJ/YD).}

Several of the UA operations in this study focused on social justice and community empowerment, which they addressed through food production and related activities. These community-based operations differed from the community gardens described above in that their activities reflect a de facto critique of the social system. Three concepts were integral to these operations' activities:

(a) Community food security (CFS), which is defined as "the ability of all persons [to obtain], at all times, a culturally acceptable, nutritionally adequate diet through local, non-emergency sources" (Gottlieb \& Fisher, 1996, p. 24); 
(b) Food justice (FJ), which considers social and economic inequities that give rise to food insecurity among various social groups, emphasizing local community control (Gottleib \& Joshi, 2010; Levkoe, 2006; People's Grocery, 2009); and

(c) Youth development (YD), which has been described as "as the natural process through which youth grow into adults; as a set of principles underlying youth programs that encourage thriving among youth; or as a set of practices that foster the development of young people" (Heck \& Subramaniam, 2009).

$\mathrm{CFS} / \mathrm{FJ} / \mathrm{YD}$ operators produced food specifically for low-income communities, fostered youth development among underprivileged youths, and/or provided job training to local residents. Each operation employed a garden or farm manager who oversaw the production of vegetables, fruits, and herbs, along with

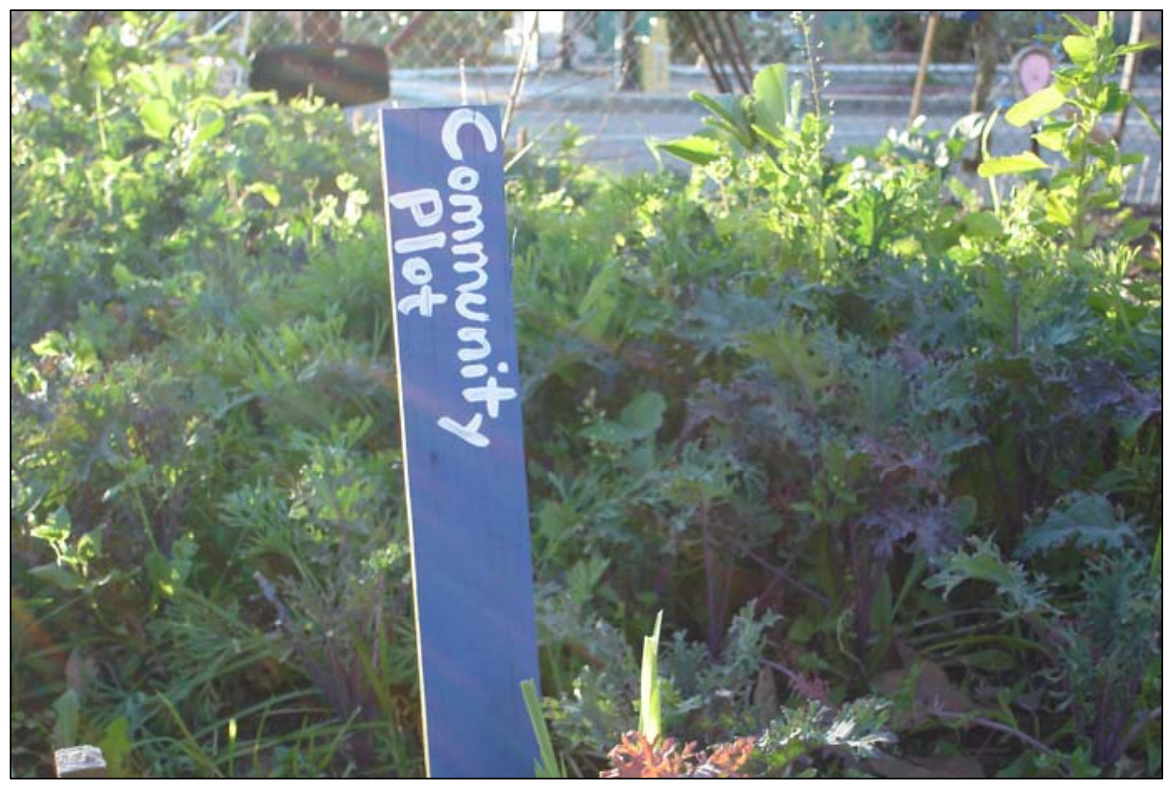

Figure 1. Community Garden (CG) Plot Photo by the author.

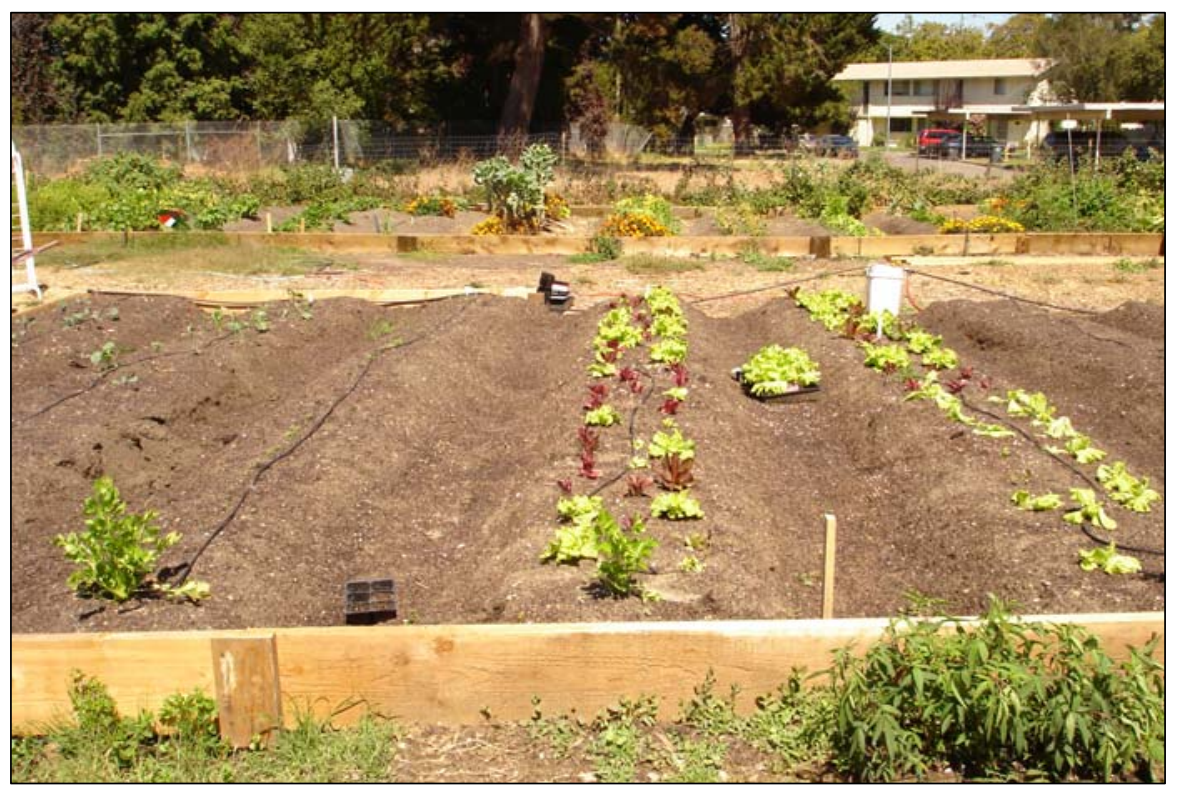

Figure 2. Vegetable Beds at a CFS/FJ/YD Farm Photo by the author. chicken- and beekeeping in some cases. Sales and distribution methods included corner farm stands, sliding-scale pricing, and a model of community supported agriculture (CSA) in which shares for lower-income members were subsidized by higherincome members' shares. Some of the operations also used direct sales through farmers' markets and high-end restaurants to increase revenue and support other activities.

The operations that incorporated YD into their programs worked mainly with youth of color in underprivileged communities to help them develop a sense of empowerment and personal responsibil- 
ity. Education about life skills such as healthy eating, seeking and maintaining employment, and community leadership was incorporated into activities that included food production, produce sales, and peer nutrition education.

Theme three: Sustainable living and self-provisioning (SLSP). Several informants practiced UA as a personal effort to live more "sustainably" and/or engage in a degree of food self-provisioning. These operators generally questioned the ecological sustainability and/or social equity of the agrifood system. As a response, they opted to produce a significant amount of their own food using what they believed to be more sustainable methods. All of these informants grew produce and herbs, and some also kept bees and/or raised small livestock, including chickens, goats, pigs, and rabbits, in their backyards. Although focused on self-provisioning, each of these operations engaged in some form of community education, including hosting occasional farm or garden tours and providing informal consultation to other urban residents.

Theme four: Commercial production. The commercial UA operations in this study were privately held, small-scale farms and ranches, and apiculture and mushroomforaging operations. Primary activities were production, harvest, and sales through various channels. Products included a wide variety of fruits and vegetables, chicken, beef, lamb, honey, and mushrooms. Sales outlets included farm stands, farmers' markets, CSAs, restaurants, agritourism, and wholesalers. Many of these operators also donated a part of their unsold produce to local food banks and other emergency food providers.

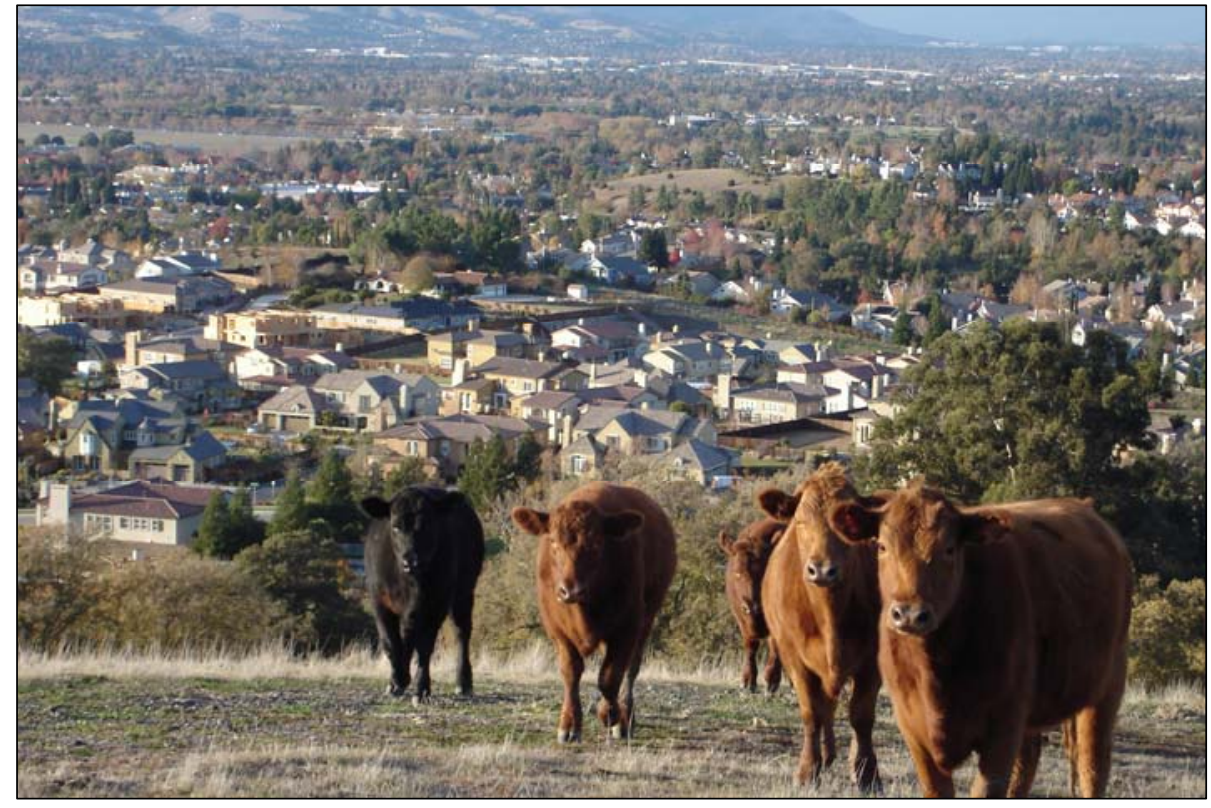

Figure 4. Commercial Cattle Ranch at a City's Edge
Photo by the author. 
While commercial production was the common theme among this set of operations, informants also expressed concerns about wider agrifood systems issues, including the decline of small farms and small-farm profitability, the ecological impacts of agricultural production, and the need to educate nonfarmers about food and agriculture.

Figure 5 shows the number of operations within each of the four themes. Figure 6 shows the distribution of sites throughout the county. In some cases multiple operations were located at one site. These are noted on the map. Additionally, some operations had multiple sites.
Figure 5. Number of Operations with Each Theme $(N=52)$

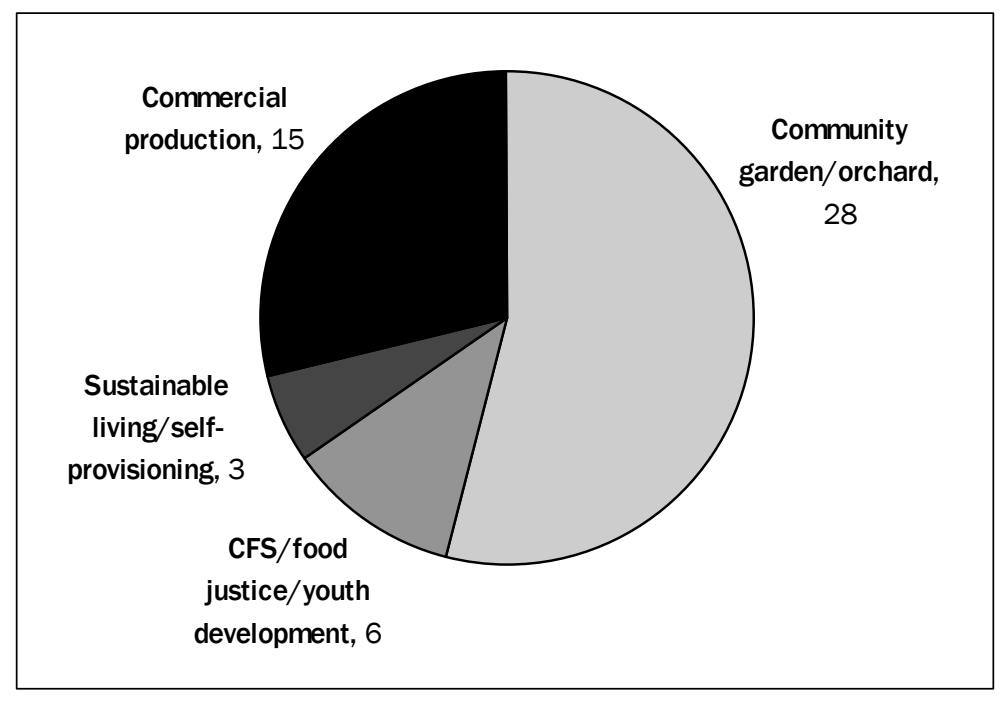

Figure 6. Urban Agriculture Sites in Alameda County, California

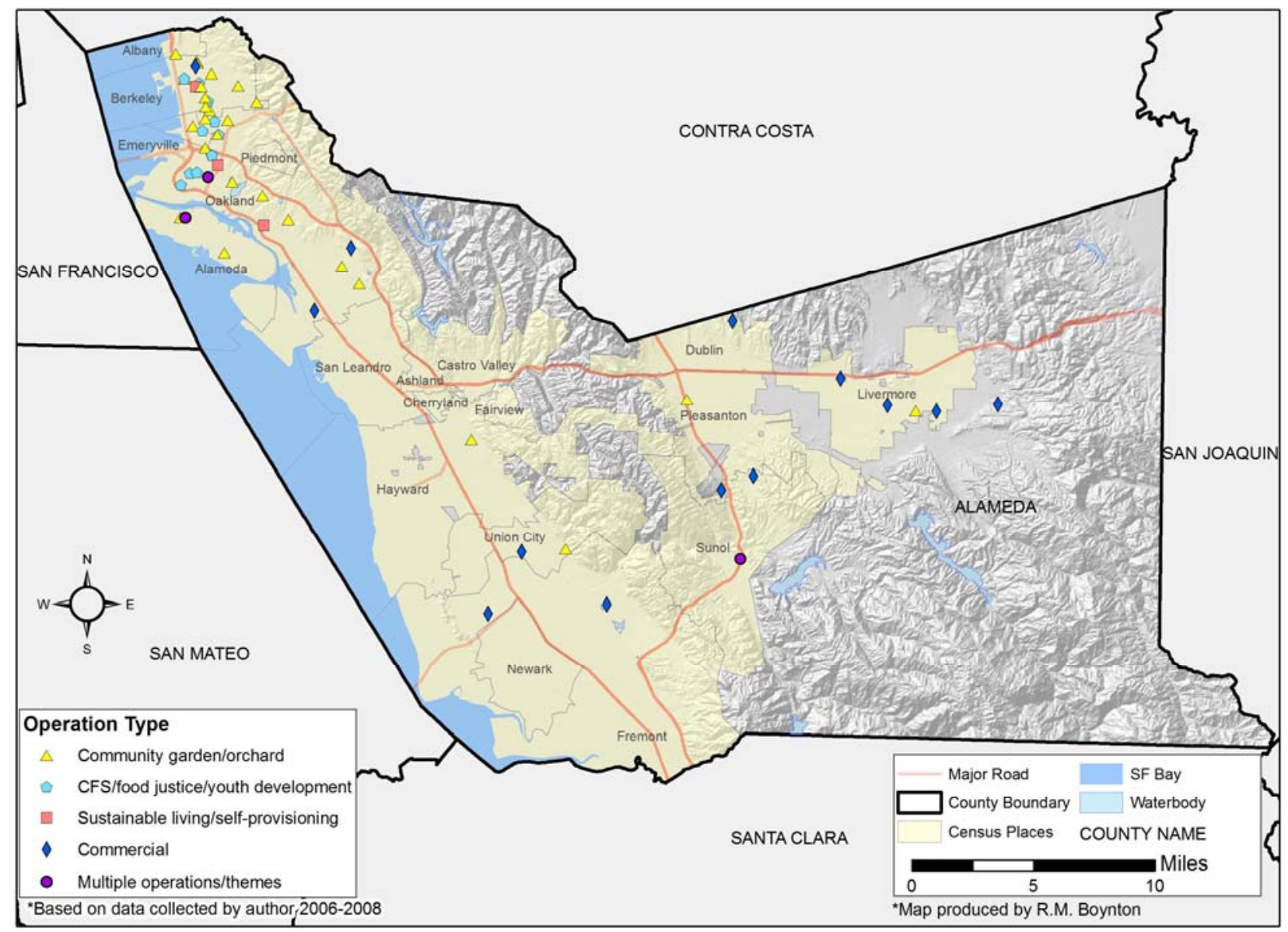




\section{Challenges}

Key informants were asked an open-ended question about their biggest challenges: What would you say are the biggest challenges to achieving your operation's goals? Responses were analyzed and grouped by the operation's main purpose, as shown in table 3 . Top challenges for each group are discussed below.

CG challenges. Top challenges mentioned by community garden informants were interpersonal relationships within the garden and time constraints. According to some key informants, community gardeners did not always come together to accomplish common tasks such as weeding paths, even when cooperation was one of the garden's stated missions. As an informant from one garden explained, a main challenge was:

to keep the work in communal areas. To develop our sense of community that goes beyond being a good gardener...to avoid

Table 3. Top Challenges Mentioned for Each Theme

\begin{tabular}{|c|c|c|c|c|}
\hline Challenges (number of responses) & $\begin{array}{c}\text { CG } \\
(n=28)\end{array}$ & $\begin{array}{c}\text { CFS } \\
(n=6)\end{array}$ & $\begin{array}{l}\text { SLSP } \\
(n=3)\end{array}$ & $\begin{array}{c}\text { Commercial } \\
(n=15)\end{array}$ \\
\hline Lack of time & 8 & 1 & 2 & 1 \\
\hline Relationship with surrounding community & 1 & 2 & 1 & 2 \\
\hline Funding (start up, expansion, paying staff) & 2 & 4 & & 3 \\
\hline Lack of agricultural infrastructure & 1 & 1 & & 2 \\
\hline Crime and/or misuse of gardena & 6 & 2 & & \\
\hline Ag not seen as a legitimate urban activity & 1 & 2 & & 1 \\
\hline Biophysical and/or environmental factors ${ }^{b}$ & 6 & & & 3 \\
\hline Lack of institutional supportc & 6 & & & 3 \\
\hline $\begin{array}{l}\text { Horticultural skills and/or knowledge (among } \\
\text { gardeners, youth, and/or volunteers) }\end{array}$ & 3 & 3 & 1 & \\
\hline Interpersonal relationships within garden & 15 & 1 & & \\
\hline Land tenure and/or cost & 2 & & 2 & \\
\hline Managing farm and/or organizational activities & & 4 & & 5 \\
\hline Costs of farming and/or cost of supplies & 1 & & & 5 \\
\hline Creating community market farm & & 3 & & \\
\hline No response & 1 & & & \\
\hline
\end{tabular}

a Violence, theft, vandalism, drug use, drug sales, and/or other use of garden for nongardening activities.

b Pests, weedy species, shade, climate, etc.

c Lack of governmental, municipal, and/or university support.

Note: Numbers total greater than the number of respondents due to multiple responses. the possessive sense that people always have... [to develop a sense that] this is a public place and we have a privilege to be here, that we don't have a right. [But this is an attitude that] you confront.

A coordinator from another garden expressed similar sentiments, noting that the "number one challenge" was the attitude of the gardeners. "They don't band together the way the South L.A. Farm and others did," she explained, making reference to the 2006 standoff between community gardeners and the landowner of a 14-acre community garden in Los Angeles (see Barraclough, 2009). She also mentioned racial tension within the garden as an example of the challenges to creating community. (The membership of this garden was ethnically diverse and was made up mostly of Mexican, but also Caucasian, West African, Japanese, and Afghan gardeners.)

Lack of time was mentioned as a challenge related to gardeners needing to schedule their gardening activities around their jobs, as well as the fact that some gardeners did not live in the neighborhood surrounding the garden.

Time was a more significant issue during the winter months because early nightfall limited visibility in many gardens and contributed to concern about personal safety, especially for women. 
CFS/FJ/YD challenges. The top four challenges mentioned by CFS/FJ/YD informants were funding; managing disparate farm and organizational activities; lack of horticultural knowledge among gardeners, youth staff, and volunteers; and creating a new type of community market farm.

Since all of the CFS/FJ/YD operations in this study were managed by nonprofit organizations, it is not surprising that funding was one of the most frequently mentioned challenges. (Funding is often a challenge for nonprofit organizations.) Specific funding issues related to starting or expanding agricultural production and paying staff. In terms of managing diverse activities, challenges related particularly to balancing farming with other responsibilities, including tasks not directly related to food production (e.g., youth counseling, fundraising, and grant-writing). These findings concur with those of past studies (see Feenstra et al., 1999; Kaufman \& Bailkey, 2000; Lawson \& McNally, 1998).

Half the CFS informants mentioned lack of horticultural skills among youth participants and volunteers as a challenge in terms of production efficiency. This challenge pertained mainly to the youths' and volunteers' limited gardening experience, whereas the adult staff members did have these skills. Rather than viewing this as wholly problematic, however, informants reiterated that youth development was one of the main goals of their UA operation; youth participants were there in order to gain these and other skills.

Half the informants also discussed the challenges associated with creating a new type of farm that was neither a community garden nor a fully commercial operation. One informant described this as "community market farming":

We call them [community market farms] to make a distinction with community gardens. But if you just say that they're market farms, that implies that they're a purely commercial endeavor, which would mean that you'd be marketing [the products] at as high a price as you could. "Community market farms" means it's run like a market farm as much as possible in terms of trying to be as productive as possible and as efficient as possible, but the food benefits — is for the community. And there's a lot of community involvement.

Other informants expressed similar concerns, noting that despite having significant gardening experience, they had needed to develop additional agronomic skills in order to manage food production for community distribution and/or sales. As one farm coordinator explained:

For us, we're like in the no-man's land between small farmers and gardeners. We're really trying to produce... on a larger scale using those types of methods, but [we] don't have all the skills and knowledge around that. [We] have never started it from the ground up.

Two of these informants mentioned that they learned farm management skills (such as strategizing successional plantings for consistent harvests and marketing) during their operation's first season.

SLSP challenges. The top challenges mentioned by SLSP informants were time and land tenure and/or cost of land. Time as a limiting factor was related to the fact that the operators of each site held one or more paid jobs that were not a part of their food-production activities. As for land tenure, each of the operations had a different land access situation, so no clear pattern emerged.

Commercial operation challenges. The two challenges cited most frequently by commercial operators were managing diverse farm activities, and the costs of farming and related effects on profitability and the ability to stay in business. While these are issues faced by small-scale farmers in general, being located in or near a city may have intensified the impact of these challenges. For example, the cost of land is typically higher in urban areas, which has been found to necessitate a higher degree of diversification and more complex 
business-management skills in order for farms to remain financially sustainable (Heimlich \& Anderson, 2001). Several other issues related more specifically to being located in an urban area. These included lack of governmental and/or institutional support for agriculture; lack of an agricultural infrastructure, including a skilled labor force, supply stores, and equipment repair services; and a lack of a network of local operators. Again, these findings concur with those of past studies (see, for example, Esseks, Oberholtzer, Clancy, Lapping, \& Zurbrug, 2008; Sokolow, 1996).

\section{Information and Assistance Needs}

In addition to discussing challenges to their operations, key informants were asked, Are there any types of information or assistance that are not available that would be useful to your operation? Again responses were aggregated and grouped by theme (see table 4).

\section{CG needs for information and assistance. The} top information and assistance needs mentioned by CG informants were networking among gardeners and collective work within the garden. Technical aspects of gardening, soil testing, food production and/or distribution resources, and business management were also mentioned. (Although most community gardens prohibited sales of produce, a few did allow gardeners to sell their produce.)

Nearly half of CG informants indicated that they did not need additional information or assistance. In a separate line of questioning, many of the informants reported getting horticultural and soiltesting information from the Internet and books, as well as the MGP. This likely explains the high percentage of "none needed" responses among these informants.

\section{CFS/FJ/YD operation needs for information} and assistance. Informants from $\mathrm{CFS} / \mathrm{FJ} / \mathrm{YD}$ operations cited three information and assistance needs equally: extension and technical research assistance (beyond gardening information); funds and staff; and compilation of information about UA practices.

Again corresponding to the challenges discussed above, specific technical needs included assistance with scaling-up from small gardens to market gardening, and periodic on-farm consultations. For instance, one farm coordinator explained her vision of an urban farming extension agent as "someone who just kind of came around and, you know, spent a few hours every other month... checking in, helping you do some farm planning," adding that "production is just a part of what I do... there's a lot of literature out there, but I don't learn by reading."

a That is, beyond gardening information.

Notes: Numbers total greater than the number of respondents due to multiple responses. 
Another informant felt that CE and other governmental agencies should do more to assist UA operators. She explained:

Through collaborative system of agricultural support in the United States, urban areas are shut out. Farm subsidies for urban agriculture [would be helpful]. Extension, government offices, a city department of food...The Extension service at the county level should have programs for urban agriculture, and cities should have a Department of Agriculture - a Department of Food.

One CFS/FJ/YD informant had specific suggestions about how to deliver information to a broad range of UA operators. He explained that "there is a lot of information, but it's hard to get because it's time-consuming." He also pointed out that "not everyone is online, or uses Internet, or can download and print documents - especially seniors who are not as familiar with computers. Having hard copies and flyers would be good for them."

\section{SLSP operation needs for information and} assistance. SLSP operators mentioned only two needs for information and assistance: gardening information and an urban agriculture extension agent. One operator explained that she and her urban-farming peers spent a considerable amount of time teaching others about farming techniques, including urban livestock husbandry. Although she was glad to share her knowledge with others, the growing number of requests had begun to take away from the time this operator was able to spend on her own farming activities. She explained that an extension agent would be very useful because "hundreds of people are getting backyard chickens and they need support - they're confused!" She also expressed a need for more technical support with raising goats: "I know there's books, but I need a person to tell me what to do. So that would be really nice if there was an urban farming extension agent...That would be awesome."

Again, the small sample size limits the inferences that can be drawn from these responses. Still, they do provide preliminary information about the types of assistance that could help individual UA practitioners.

\section{Commercial operation needs for information} and assistance. Eleven of the 15 commercial operators stated that no additional information or assistance was needed. Several informants, especially beginning operators, indicated that they typically accessed information through the Internet or other resources, and/or had personal connections with other farmers on whom they called for assistance when needed. Some of the more seasoned commercial operators indicated that they relied upon their own experience in making management decisions.

Despite the fact that the majority of commercial operators in this study indicated not needing additional assistance, several informants did mention that information about farm business management would be useful. One operator explained that producing in an urban area meant that he did not have connections with other producers who might provide him with guidance on managing his farm business. Another operator stated that more extension personnel were needed "to buffet resistance to agriculture" in the area. He explained: "It's working in reverse. We need more [help] to educate the urban people, and we're not gettin' it from Extension. They've cut out the personnel [but] people take food for granted in this country."

"None Needed" responses. As discussed above, many informants indicated no need for additional information or assistance. It is important to reiterate that this question specifically addressed assistance and information needs. It did not probe other issues such as policy, zoning, or advocacy. Moreover, informants' knowledge that the study was being conducted through an extension program likely influenced responses. For instance, policy change was not mentioned as a "need," although comments made during some of the interviews suggested that policy changes would help overcome certain challenges. To this end, future research should explore UA practitioners' opinions of 
needed policy changes, zoning, and advocacy more explicitly.

\section{Findings Part Two: Extension Staff}

As described above, the second population of interest in this study (Extension staff) consisted of SFP advisors, members of the UC Small Farm Workgroup, and staff members from UCCE Alameda. Facilitated discussions and email surveys revealed several key points about their understanding of UA and interest in working with UA operators.

Definition of urban agriculture. Over the course of the study, several Extension staff indicated a lack of clarity about the term "urban agriculture." This was surprising since each facilitated discussion and survey was prefaced with the definition used in this study. ${ }^{6}$ One farm advisor wrote:

To be honest, I still have trouble with the definitions - "Urban" [is] agriculture within the city boundaries; "peri" [is] just on the edges and outside the city. But where do you draw the line between rural and peri [urban]?? And is one more commercial (peri-) and the other community garden (urban)? I don't think so. In the context of our jobs both are commercial to me. I used to just call it all "commercial farming on the urban-rural interface."

Several advisors also mentioned that most of their clientele would be considered urban producers, as explained in an email from another advisor:

I would say that the majority of farmers I work with $(>80 \%)$ are strongly influenced by the ag-urban interface and would have major concerns over most, if not all, of the areas mentioned [as characteristics of urban agriculture]...Essentially all of [southern California] west of Riverside, as

\footnotetext{
${ }^{6}$ The term "peri-urban" was replaced by "urban edge" over the course of the study because it became apparent that nonacademic stakeholders often were confused by the term as used in much of the UA literature.
}

well as all of the coast, as well as a solid wide band from San Bernardino thru Bakersfield, Fresno, and then the [northern San Joaquin] Valley. There would only be pockets of areas that would be NON urban or peri-urban by the definition here.

This lack of clarity about urban agriculture is important to note in terms of its potential effects on expanding UA extension programs. As a case in point, this study relied upon definitions typically used within the UA movement, yet these were not meaningful to farm advisors. While the study was developed in order assess the need for a UA extension program, much of the dialogue between Extension staff members during the three-year study process centered on how urban agriculture was defined rather than whether or not a new program should be developed.

Identifying and working with clientele. Just as farm advisors did not conceptualize agriculture itself as "urban" or "nonurban," several advisors emphasized they did not identify their target clientele based upon location (i.e., whether they produced in urban or rural areas). Rather, advisors distinguished between commercial and noncommercial operators, explaining that they viewed small-scale commercial producers as their target clientele, and referred noncommercial operators to the MGP for assistance.

As discussed above, not all UA operators in this study were involved in the commercial sector, but this did not mean that they were growing food simply as a hobby or leisure activity. Some operators grew and distributed food that essentially bypassed the conventional market structure, which had failed (whether by design or neglect) to meet the needs of their communities. Others relied upon food they produced themselves, including animal products, to feed household members. This suggests a need for more extension assistance for UA operators whose food-production goals are neither leisure nor fully commercial, and/or whose farming activities extend beyond horticulture.

Past work with UA operators. Despite farm 
advisors' focus on commercial operations, it is important to point out that several advisors had worked with noncommercial urban gardeners and farmers in the past, and continued to do so. Activities ranged from conducting crop variety workshops for gardeners to helping establish noncommercial urban farms and community gardens. Additionally, several Extension staff members indicated an interest in addressing additional UA topics in the future. Responses to surveys emailed at strategic points throughout the study indicated particular interest in community-based food systems research and efficient use of vacant land for food production, along with a more general interest in connecting small-scale farmers with urban markets. To be clear, some farm advisors questioned whether certain issues such as nutrition or urban food policy fell within their domain. Still, the interest expressed by several advisors and staff members suggests the possibility of moving beyond a piecemeal approach to assisting UA operators, to a more coordinated one.

\section{Discussion and Recommended Practices}

This article has attempted to provide baseline information about the dynamics of urban agriculture in one California county, as well as perspectives about UA held by farm advisors and other Extension staff. The findings of this study build upon past research by offering a framework for conceptualizing UA based on main purpose, and exploring how purpose may correlate with challenges and operators' need for technical assistance. It has also provided perspective on how operators' and farm advisors' understandings of urban agriculture may differ, and how this might affect future efforts to expand UA Extension programs. Four overarching recommendations may be useful to this end.

First, as suggested by its six areas of focus, the Cooperative Extension system has the institutional capacity to address many (though perhaps not all) of the information and assistance needs identified by UA operators in this study. In addition to topics addressed by existing programs, Extension programs for urban agriculture should include assistance with:
- market gardening (i.e., crop planning for community food production and distribution);

- urban livestock husbandry (e.g., basic livestock and beekeeping skills);

- $\quad$ soil testing, including information about the importance of testing soils in urban areas, where to have tests done, how to interpret results, and how to minimize risks of contamination;

- marketing;

- business management for both commercial and noncommercial operations;

- community development, including networking, community relationships, intercultural relationships, and antiracism; and

- educating nonfarmers about the importance of agriculture in urban areas.

Second, because the way in which UA is defined can affect the availability of extension assistance, efforts to expand technical support and educational programs should begin with the development of a context-specific definition of UA. Care should be taken to include all types of UA activities in a given area, as well as systematic assessments of clientele (i.e., the full spectrum of UA operators), their diverse needs, and the accessibility of Extension services regardless of location, technological capabilities, etc. All stakeholder groups should be represented fairly in such processes.

Third, an important factor related to social justice in the food system that has not been addressed in this article is the history of discriminatory practices enacted by the USDA toward African American, Native American, Latino, and women farmers (see Farm and Food Policy Diversity Initiative, 2009; Hoffman, 2009; MacPherson, 2006; Myers, 2001; Treviño, 2009). This, along with the links between race, income, and urban food access discussed in the beginning of this article, underscores the need to place priority on serving the full spectrum of UA operators from all racial and ethnic groups. Program development should evolve with the 
expectation that some groups may need more substantial assistance than others, whether this is due to economic status, educational attainment, access to technology, or systemic inequalities. To this end, USDA agencies, including Cooperative Extension, might learn effective strategies from UA operators who have actively worked to address issues of food justice and community empowerment through their programs.

Finally, as noted above, the CE system is in a budget crisis that has brought an end to many programs in recent years, as the budgetary changes did for the Urban Garden Program in the 1990s. While this reality may limit the development of new programs that require additional financial and human resources, it may also present an opportunity for $\mathrm{CE}$ to engage more fully in cooperation with urban farming and gardening communities.

As discussed in this article, UA operators have innovated production, marketing, and communityempowerment approaches through experience and knowledge exchange. A commitment on the part of CE to learning from, along with providing assistance to, UA operators may be a next step in expanding the practice of sustainable urban food production. This work should be approached through cooperation, dialogue, and a commitment to co-learning. By integrating these approaches into future work with urban agriculture, the Cooperative Extension system may be able to participate more fully in realizing the profound and lasting changes that are needed to create a more sustainable and socially just urban food system - in California and beyond.

\section{Acknowledgements}

This research was funded in part by a grant from the USDA Risk Management Agency. It was also supported by the University of California Small Farm Program and the UC Davis Geography Graduate Group. UCCE Alameda provided access to important historical information.

I am grateful to the staff of the UC Small Farm Program for their ongoing support of this project over a period of several years, and to my disserta- tion advisors, Dean MacCannell, Gail Feenstra, and Mark Francis at UC Davis, for their guidance through all stages of this project. I am also grateful to Nevin Cohen at The New School for his comments on sections of this article and to the three anonymous reviewers whose critical comments made this a much better piece. Finally, I extend my gratitude to the research participants - urban agriculture operators and Extension staff members - who contributed time and knowledge to this research, and who continue to work to improve the agrifood system in all its parts.

\section{References}

Alkon, A. (2008). Black, white, and green: A study of urban farmers markets (Doctoral dissertation). University of California, Davis. Retrieved from ProQuest (Publication number 3336210).

American Farmland Trust. (n.d.) Ranchettes \& other development outside city spheres of influence. In Central $V$ alley Farmland at the Tipping Point. Retrieved from http://www.farmland.org/programs/states/ futureisnow/ranchettes.asp

Ashton, A. (2003). Community gardens and open space: A study of place and community in two Bay Area communities (Unpublished master's thesis). University of California, Davis.

Balmer, K, Gill, J., Kaplinger, H., Miller, J., Peterson, M., Rhoads, A.,...Wall, T. (2005). The diggable city: Making urban agriculture a planning priority. Portland State University. Retrieved from http://www.diggablecity.org/

Barraclough, L. (2009). South Central farmers and Shadow Hills homeowners: Land use policy and relational racialization in Los Angeles. The Professional Geographer, 61(2), 164-186. doi:10.1080/00330120902735767

Bellows, A., Brown, K., \& Smit, J. (2003). Health benefits of urban agriculture: Public health and food security. Community Food Security Coalition. Retrieved from http://www.foodsecurity.org/pubs.html

Bellows, A., Robinson, V., Guthrie, J., Meyer, T., Peric, N., \& Hamm, M. (2000). Urban livestock agriculture in the state of New Jersey, USA. Urban Agriculture Magazine, 2, 8-9. Retrieved from http://www.ruaf.org/node/100

Beyers, M., Brown, J., Cho, S., Desautels, A., Gaska, K., Horsley, K.,...Anderson, S. M. (2008). Life and death from unnatural causes: Health and social inequity in Alameda County. Alameda County Public Health Department, Community Assessment, Planning, Education, and Evaluation (CAPE) Unit. Available at http://www.acphd.org/AXB YCZ/Admin/DataReports/00 2008 full report.pdf

Blecha, J. L. (2007). Urban life with livestock: Performing alternative imaginaries through small-scale urban livestock agriculture in the United States (Unpublished doctoral dissertation). University of Minnesota. Retrieved from ProQuest (Publication number 3273113). 
Bray, D. (2008). Alameda County 2007 crop report. Alameda County Department of Weights and Measures: Hayward, California. Retrieved from http://www.acgov.org/cda/awm/resources/stats.htm

Brown, K. (2002). Urban agriculture and community food security in the United States: Farming from the city center to the urban fringe. Community Food Security Coalition. Retrieved from http://www.foodsecurity.org/pubs.html

Brown, K., \& Carter, A. (2003, October). Urban agriculture and community food security in the United States: Farming from the city center to the urban fringe. Prepared by the Community Food Security Coalition's North American Urban Agriculture Committee. Available at http://www.foodsecurity.org/ PrimerCFSCUAC.pdf

Burros, M. (2009, March 16). Obamas to plant vegetable garden at White House. The New York Times. Retrieved from http://www.nytimes.com/2009/03/20/dining/ 20garden.html

California Department of Conservation, Division of Land Resource Protection. (2008, December). California Farmland Conversion Report, 2004-2006. County Summary and Change by Land Use Category, Table A-1 Alameda County.

Cozad, S., King, S., Krusekopf, H., Prout, S., \& Feenstra, G. (2002). Alameda County foodshed report (pp. 1-68). Davis, California: University of California Sustainable Agriculture Research and Education Program. Retrieved from http://www.sarep.ucdavis.edu/CDPP/Report/ alamedareport.pdf

Drescher, A. (2002). Food for the cities: Urban agriculture in developing countries. Paper presented at the International Conference on Urban Horticulture, Wadenswil, Switzerland.

Dufour, R. (2009). Start a farm in the city: Change your community by growing what you eat. NCAT/ATTRA. Retrieved from http://www.attra.org/attra-pub/PDF/farmcity.pdf

Eizenberg, E. (2008). From the ground up: Community gardens in New York City and the politics of spatial transformation (Unpublished doctoral dissertation). City University of New York, New York. Retrieve from ProQuest (Publication number 3325374).

Esseks, D., Oberholtzer, L., Clancy, K., Lapping, M., \& Zurbrug, A. (2008). Sustaining agriculture in urbanizing counties: Insights from 15 coordinated case studies. Lincoln: Center for Great Plains Studies, University of Nebraska.

Farfan-Ramirez, L. (n.d.). Cultivating bealth: $A$ West Oakland food security planning project: A profile of West Oakland neighborhoods-Part II. (Unpublished work) University of California Cooperative Extension, Alameda County.

Farfan-Ramirez, L., \& Kelly, M. (n.d.). Cultivating health: $A$ West Oakland food security planning project: A profile of West Oakland neighborhoods-Part I. (Unpublished work.) University of California Cooperative Extension, Alameda County.
Farm and Food Policy Diversity Initiative. (2009). A seat at the table: Diversity and the 2008 Farm Bill. A report on the Farm and Food Policy Diversity Initiative. Rural Coalition/Coalición Rural. Retrieved from http://ruralco.org/shaping using farm bill.html

Feenstra, G., McGrew, S., \& Campbell, D. (1999). Entrepreneurial community gardens: Growing food, skills, jobs, and communities. Davis: University of California Division of Agriculture and Natural Resources.

Francis, M. (1987). Some different meanings attached to a city park and community gardens. Landscape Journal, 6(2), 101-112.

Francis, M. (1989). Control as a dimension of public-space quality. In I. Altman and E. Zube (Eds.), Public spaces and places (pp. 147-172). New York: Plenum.

Fuller, A. (n.d.). A bistory of food insecurity in West Oakland, CA: Supermarket location. Unpublished student paper given to University of California Cooperative Extension, Alameda County.

Geisel, P., \& Feathers, L. (n.d.). Master Gardener Program: $A$ synopsis for California 1980-2006 (p. 29): University of California Division of Agriculture and Natural Resources. Retrieved from http://camastergardeners.ucdavis.edu/files/28293.pdf

Gibby, D., Scheer, W., Collman, S., \& Pinyuh, G. (n.d.). The Master Gardener Program: A WSU Extension success story: early history from 1973. In T. Fitzgerald (Ed.), Washington State University Extension Statewide Master Gardener Program (pp. 1-3). Retrieved from http://mastergardener.wsu.edu/documents/Master GardenerProgramHistoryrev2009.8.pdf

Gottlieb, R., \& Joshi, A. (2010). Food justice. Cambridge: MIT Press.

Gottlieb, R., \& Fisher, A. (1996). Community food security and enviromental justice: Searching for a common discourse. Agriculture and Human Values, 3(3), 23-32. doi:10.1007/BF01538224

Guthman, J. (2003). Fast food/organic food: Reflexive tastes and the making of "yuppie chow." Social and Cultural Geography, 4(1), 45-58. doi:10.1080/1464936032000049306

Heck, K., \& Subramaniam, A. (2009). Youth development frameworks. Davis, California: University of California 4-H Center for Youth Development. Retrieved from http://www.ca4h.org/files/29164.pdf

Heimlich, R. E., \& Anderson, W. D. (2001). Development at the urban fringe and beyond: Impacts on agriculture and rural land. Washington, DC: USDA Economic Research Service. Retrieved from http://www.ers.usda.gov/Publications/ AER803/

Heynen, N. (2009). Bending the bars of empire from every ghetto for survival: The Black Panther Party's radical antihunger politics of social reproduction and scale. Annals of the Association of American Geographers, 99(2), 406422. doi:10.1080/00045600802683767 
Hoffman, J. (2009). The last plantation. ColorLines, 1-3. Retrieved from http://www.colorlines.com

Hyden-Smith, R. (2009). Victory Grower website. Retrieved from http://groups.ucanr.org/victorygrower/ aboutworkgroup.htm

Hynes, P. H. (1996). A patch of Eden: America's inner-city gardens. White River Junction: Chelsea Green.

Hynes, P. H., \& Howe, G. (2002). Urban horticulture in the contemporary United States. Paper presented at the International Conference on Urban Horticulture, Wadenswil, Switzerland.

Jolly, D. (2009). Small farms shortchanged again. Davis Enterprise. October 24, 2009.

Jones, P., Ona, F., Rimkus, L., \& Wells, Z. (2005). 2005 San Francisco collaborative food assessment. San Francisco: San Francisco Food Alliance.

Kaufman, J., \& Bailkey, M. (2000). Farming inside cities: Entrepreneurial urban agriculture in the United States (Lincoln Institute of Land Policy Working Paper), (pp. 1-120): Lincoln Institute of Land Policy. Retrieved from http://www.lincolninst.edu/pubs/260 LandLines---January-2001--Volume-13--Number-1

Lawson, L. (2005). City bountiful: A century of community gardening in America. Berkeley: University of California Press.

Lawson, L., \& McNally, M. (1998). Retbinking direct marketing approacheds appropriate to low- and moderate-income communities and urban market gardens (p. 11). Davis, California: University of California Sustainable Agriculture Research and Education Program.

Levkoe, C. (2006). Learning democracy through food justice movements. Agriculture and Human V alues, 23, 89-98. doi:10.1007/s10460-005-5871-5

Lofland, J., Snow, D., Anderson, L. \& Lofland, L. (2006). Analyzing social settings: A guide to qualitative observation and analysis (4th $e$ d.). Belmont, CA: Wadsworth/Thomson Learning, Inc.

Los Angeles County Cooperative Extension. (n.d.). Common Ground Garden Program. Retrieved from http://celosangeles.ucdavis.edu/Common Ground Garden Program/

MacPherson, J. (2006). Native American ranchers denounce racism in USDA. Retrieved from http://www.organicconsumers. org/articles/article_3059.cfm

Malakoff, D. (1994). Final harvest? How the federal government's Urban Gardening Program flourishedthen faltered. Community Greening Review, 4, 4-12.

McClintock, N. (2008). From industrial garden to food desert: Unearthing the root structure of urban agriculture in Oakland, California. In Institute for the Study of Social Change Change Working Paper Series 2007-2008. Berkeley: University of California. Available from http://escholarship.org/uc/item/1wh3v1sj

McClintock, N., \& Cooper, J. (2009). Cultivating the commons: An assessment of the potential for urban agriculture on Oakland's public land. Berkeley: University of California. Available from http://www.oaklandfood.org
McGrew, S. (1999). The land of opportunity: Cultural negotiation in a Hmong community garden (unpublished master's thesis). University of California, Davis.

Monroe-Santos, S. (1998). Improving permanany for urban community gardens (unpublished master's thesis). University of California, Davis.

Mougeot, L. (Ed.). (2005). Agropolis: The social, political, and environmental dimensions of urban agriculture. Ottawa: Earthscan and IDRC.

Myers, G. (2001). Where have all the Black farmers gone? California Certified Organic Farmers Magazine, 17.

National Institute of Food and Agriculture (NIFA). (2011). About us. Retrieved January 28, 2011, from http://www.csrees.usda.gov/qlinks/extension.html

People's Grocery. (2009). Mission \& history. Retrieved from http://www.peoplesgrocery.org/index.php?topic= aboutus

Pothukuchi, K., \& Kaufman, J. (1999). Placing the food system on the urban agenda: The role of municipal institutions in food systems planning. Agriculture and Human Values, 16, 213-224. doi:10.1023/A:1007558805953

Reynolds, K. (2009). Urban agriculture in Alameda County, CA: Characteristics, challenges, and opportunities for assistance. UC Small Farm Program Preliminary Research Findings. Davis: University of California. Available from http://sfp.ucdavis.edu/docs/urban agriculture09.pdf

Reynolds, K. (2010). Urban agriculture as revolution: An action research and social movement analysis of food production in Alameda County, California (Unpublished doctoral dissertation). University of California, Davis. Available from ProQuest (publication number 3404965) and http://www.cityfarmer.info/2010/06/13/ph-d-thesisurban-agriculture-as-revolution-an-action-research-andsocial-movement-analysis-of-food-production-inalameda-county-california/

Schertenleib, R., Forster, D., \& Belevi, H. (2002). An integrated approach to environmental sanitation and urban agriculture. Paper presented at the International Conference on Urban Horticulture, Wadenswil, Switzerland.

Short, A., Guthman, J., \& Raskin, S. (2007). Food deserts, oases, or mirages? Small markets and community food security in the San Francisco Bay Area. Journal of Planning Education and Research, 26, 352-364. doi:10.1177/0739456X06297795

Small Farm Program Small Farm Program has a new address. Retrieved from http://www.sfp.ucdavis.edu

Smit, J., Ratta, A., \& Nasr, J. (1996). Urban agriculture: Food, jobs, and sustainable cities. New York: UNDP.

Sokolow, A. D. (Ed.). (1996). Community and university: Case studies and commentary on University of California Cooperative Extension interventions. Davis: University of California Division of Agriculture and Natural Resources.

Stephens, J. M., DelValle, T. B., Daniels, B., \& Oehler, M. K. (1996). Jacksonville's Urban Gardening Program: 19771996. Proceedings of the Florida State Horticultural Society, 109: 294-296. Available at http://www.fshs.org/ 
Treviño, M. (2009). Hispanic farmers struggling to survive against USDA-sanctioned discrimination and institutionalized racism. Retrieved from http://www.latinalista.net/palabrafinal/ 2009/06/hispanic farmers struggling to survive a.html

Tsai, S. (2003). Needs assessment: Access to nutritious foods in East Oakland and South Hayward (unpublished tudent paper for interdisciplinary program). Berkeley, CA: UC Berkeley School of Public Health, Alameda County Public Health Department.

U.S. Census Bureau. (2008). U.S. Census Quickfacts. Retrieved from http://quickfacts.census.gov

U.S. Department of Agriculture (USDA). (2002). Census of Agriculture.

U.S. Department of Agriculture (USDA). (2007). Census of Agriculture.
Unger, S., \& Wooten, H. (2006, May 24). A food systems assessment for Oakland, CA: Toward a sustainable food plan. Oakland, CA: Oakland Mayor's Office of Sustainability and University of California, Berkeley, Department of City and Regional Planning. Retrieved from http://oaklandfoodsystem.pbworks.com/f/ Oakland $\% 20$ FSA 6.13.pdf

University of California Cooperative Extension Alameda County. (n.d.). Home page. Retrieved from http://cealameda.ucdavis.edu/

van Veenhuizen, R. (Ed.). (2006). Cities farming for the future: Urban agriculture for green and productive cities. Ottowa: RUAF Foundation, IDRC, IIRR. 